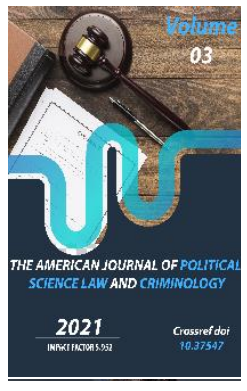

Journal Website: http://usajournalshub.c om/index,php/tajpslc

Copyright: Original content from this work may be used under the terms of the creative commons attributes 4.0 licence.

\section{A Comparative Study Of The Economic Crime In Uzbekistan And India: A Critical Analysis}

\author{
Azizakhon Avazxonovna Allanova \\ Lecture Of The Department Of Criminal Law, Criminology And Fight Against Corruption of \\ Tashkent State University Of Law, Uzbekistan \\ Choudhoury Kaustav \\ Assistant Professor (Law) Rashtriya Raksha University (An Institution Of National Importance), \\ Ministry Of Home Affairs, Government Of India
}

\title{
ABSTRACT
}

This article discusses a comparative study of the economic crime in Uzbekistan and India: a critical analysis.

\section{KEYWORDS}

Crime, economic crime, Uzbekistan, India

\section{INTRODUCTION}

Crime in the field of economics is explained by the fact that it is inherently variable and complex, requires constant study, and because of these aspects it is not possible to define it definitively. This poses a number of challenges in improving legislation against economic crime.

The problem of crime in the field of economics has been of interest to researchers since the earliest days of this phenomenon. Early 
research in this area began with the study of its types related to property encroachment.

There are various definitions of the concept of crime in the field of economics, but it was first known to the public as "white collar crime". The author of the phrase, the American criminologist E. Saderland, in 1940 he called the set of offenses committed by high-ranking officials in the course of their professional duties a "white-collar crime." Well-known Swedish scholar B. Svenson described economic crimes as greedy crimes committed in the course of economic activity[1].

\section{THE MAIN RESULTS AND FINDINGS}

To date, the scale of economic crime has expanded significantly. This category of crimes also includes tax evasion, computer-related crimes and similar acts that harm the state economy, its separate branches, business activities, the interests of certain groups of citizens.

Many Russian scholars, including NF Kuznetsova, believe that economic crimes consist of encroachment on property and crimes in the field of entrepreneurship[2].

V.V. According to Luneev, in countries with market economies, the basis of economic crimes is the criminal actions committed by corporations against the state economy, other corporations, consumers, as well as employees of corporations against these corporations[3].

As for the scientific approaches to the study of crimes against the fundamentals of economics, the concept of "economic crime" (or crimes against the fundamentals of the economy), along with the concepts of "organized crime" and "money laundering", criminologists and law enforcement firmly rooted in the apparatus of concepts[4].

The composition of the crime is the basis for the determination of criminal liability on the basis of which the dispositions of the norms of the Special Part of the CC are formed. Also the absence of the necessary signs of the objective side in a particular case, the composition of the crime means that it does not exist[5].

Among the signs of the objective side of a particular crime are the essential typical signs of the external side of this type of crime in their generalized expression, distinguished from the countless possible manifestations of the corresponding type of crimes committed in reality [6].

The elements of the crime are strengthened in the norms of the General and Special Parts of criminal law. The presence of all the elements of the crime in the act is the basis for finding it a crime and prosecuting the perpetrator[7].

In cases where threat is manifested as an element of the objective aspect of another crime, it serves as a way and means to break the victim's resistance, to influence his psyche in order to intimidate him with this or that kind of injury if he does not comply with the guilt [8].

In practice, a crime against the fundamentals of economics is a series of dozens of offenses under the criminal law (looting of another's property, illegal transactions with foreign exchange, making or transferring counterfeit money or securities, and withholding income from the tax authorities). concealment, illegal business, smuggling, etc.). Some authors consider economic crimes to be official crimes of greed, especially bribery. Thus, economic crime is characterized by a high level of social 
risk, a negative impact on the institutions of society, a violation of the material basis of the state - the established order of economic activity. It is characterized by some peculiarities:

1. The latency of crimes against the fundamentals of economics is much higher. Such crimes are committed by persons authorized to manage property and ensure its integrity. The latency rate of some new types of economic crimes is relatively low (e.g., fraud in obtaining bank loans). The same can be said about the level of latency of a dangerous crime such as counterfeiting.

2. Crimes against the fundamentals of the economy cause great harm to society.

3. Crimes against the fundamentals of the economy can become a way of life for the majority of the population, forming a semicriminal mentality. In Russia, for example, more than 10 million people import and sell goods. Studies show that almost all of them violate the rules of payment of duties, conceal income from the tax authorities.

4. Crimes against the fundamentals of economics are by their nature almost entirely organized. In most foreign countries, organized crime mainly controls the sources of criminal income - casinos, drugs, racketeering, arms sales, while in some countries (for example, Russia) it controls the entire economy.

E.E. Dementeva summarizes the views of US and German criminologists that economic crime is a violation of the interests of the state economy as a whole, as well as private entrepreneurship and certain groups of citizens, under the guise of legitimate economic activity by both individuals and legal entities. It is an illegal activity, "he said.

The concept of economic crimes is defined in the Criminal Code of the Republic of Uzbekistan as socially dangerous acts that harm the national economy, its industries or sectors or pose a real risk of such damage. The commission of such crimes causes material damage to individuals, public associations or the state. In this context, it can be said that in assessing the protection of economic interests from criminal encroachment as the object of this type of crime, economic crimes are considered as the basis of social relations and the basic system within it. The interests of the economy are expressed in the relations related to the distribution of material goods, their production and use, as well as in the distribution of the products of labor.

By crimes in the economic sphere, we mean socially dangerous acts defined in the Criminal Code of the Republic of Uzbekistan, which harm the national economy, its branches or branches, or pose a real risk of such harm. In the third section of the Criminal Code of the Republic of Uzbekistan, the crimes in the economic sphere were recorded. We can divide the crimes in the economic sphere into the following types:

Crimes related to looting of other people's property.

Crimes not related to the looting of the property of others.

Crimes against economic basics.

Crimes in the sphere of economic activity.

Crimes related to sabotage of business activities, unlawful interference and other 
crimes that infringe on the rights and legitimate interests of business entities.

In all of these crimes in the economic sphere, the related object is the social relations that provide important interests in the economic sphere. The interests of the economy are expressed in the relations related to the distribution of material goods, their production and use, as well as in the distribution of the products of labor.

In committing acts related to illegal financial transactions, the subject always seeks economic gain, material gain. In this regard, it is appropriate to cite the fundamentals of economics as the object of acts related to illegal financial transactions[9].

Objectively, crimes related to economic area are coded in action or inaction. Crimes in the economic sphere can also be divided into types of crimes (formal) that determine the condition of causing certain consequences (material content) or do not provide for the occurrence of such consequences as necessary features. In order to assess the completion of a crime in a crime in a material economy, it is necessary to have a certain consequence provided by law. In the formal compositional types of crimes in the economic sphere, the fact that an act representing the objective aspect of the crime provided for in the norm of the law signifies the completion of the crime. In crimes in the economic sphere, the the main thing is the identification of the causal link between this act and the resulting criminal consequence. This is because a causal link means that any circumstance that has not been identified will not produce the content of the offense under analysis.
The culprit of crimes in the economic area may be a 16-year-old mentally sane physical person.

The subjective aspect of crimes in the economic area can be both negligence and negligence.

Studying the experience of India in foreign countries, including developed countries, on economic crimes, of course, provides an opportunity to better understand the relationship in this area, comparative analysis of established norms, identify gaps and shortcomings in existing legislation and develop specific proposals and recommendations.

The term economic offences define those crimes which are of an economic nature. These offences are committed while in the course of some kind of economic or business activity. Although in some parts of the world, like the United States, the term economic offences have been defined, a rigorous definition of this term is still lacking in India. This is the reason why it is difficult to pinpoint the kinds of crimes that come under the term of economic offences in India.

The National Crimes Report Bureau of India still classifies only specified acts under the term economic offences. Activities like company frauds, counterfeiting of coins, and some of the terrorist activities even come under the term Economic offences in the Indian context provided by the NCRB. While certain explanations are provided for this term it still lacks a proper definition which is not vague or ambiguous in nature.

According to Indian criminal law, economic crimes have the following characteristics: 

a) An economic offence needs to have the required actus reus and mens rea before the commission or omission of the act.
b) The intention behind committing an economic offence is to have some kind of material advantage or to avoid or reduce some kind of material loss. The motive can also be of causing some kind of a material loss to the third party with complete knowledge of such loss.
c) Economic offences generally imply the existence of certain elements like a breach of trust, deception or cheating.
d) Economic offences generally don't involve any kind of physical harm caused by its commission.
e) This kind of crime is mostly committed
practice the principles of justice and humanity, to reduce the repressive functions of punishment[10].

\section{CONCLUSION}
National laws and legislations are not adequate enough for reacting and dealing with challenges that are cross border in nature and that involve multiple jurisdictions and a multiplicity of laws. The increased growth in globalisation and global economic crimes require a global response. At present, the measures that are there are all at national levels, but all these measures differ from country to country. Thus, it becomes all the more important for countries to have increased cooperation between the world's law enforcement agencies. by the privileged or the upper-class section of the society, who have access to such economic or business activities as well as the required resources.

The types of economic crimes in India are:

Economic offences in India can be classified into three categories. These categories of economic offences are:

1) Traditional economic crime which includes corruption, smuggling, bogus imports etc.

2) Emerging technological economic crimes that include credit card frauds, counterfeiting, cyber crimes etc.

3) Crimes through which proceeds of transnational organized crime are transmitted abroad like money laundering.

From the first days of independence, the criminal policy has been gradually liberalized, the main purpose of which is to put into

\section{REFERENCES}

1. Abdurasulova Q.R. Criminology. Tashkent: TDYul, 2008. - P.205-206

2. Kuznetsova N.F Codification norm $O$ hozyaystvennyx prestupleniyax // Vestnik Moskovskogo Universiteta. - Ser.11. Pravo, 1993. №4. - S.12

3. Luneev V.V. Prestupnost XX century. $-M$.: 1997. - S.257

4. Abdurasulova Q.R. Criminology. T.: TDYul.2008. 205 bet.

5. Худайкулов Ф. Х. Жиноят таркиби объектив томони зарурий ва факультатив белгиларининг жиноятхуқуқий ахамияти: тахлил ва таклиф //ЖУРНАЛ ПРАВОВЫХ ИССЛЕДОВАНИЙ. - 2021. - T. 6. - №. 1.

6. Khudaykulov F. K. Signs Of The Objective Side Of Crime In The Theory Of Criminal Law Belonging To The Romano-Germanic Legal Family: Theoretical And Practical 
Problems //The American Journal of Political Science Law and Criminology. 2021. - T. 3. - №. 01. - C. 57-62.

7. Худайкулов Ф. Х. Қилмишни квалификация қилишда жиноят таркиби зарурий ва факультатив белгиларининг ўрни: тахлил ва таклиф //ЖУРНАЛ ПРАВОВЫХ ИССЛЕДОВАНИЙ. - 2020. - Т. 5. - №. 1.

8. Khudaykulov F. K. Force And Threat Of Violence Are As The Ways Of Commission Of Rape: National And Foreign Experience //Psychology and Education Journal. 2021. - T. 58. - №. 1. - C. 1123-1132.

9. Шамсидинов 3. 3. НОқОНУНИЙ МОЛИЯВИЙ ОПЕРАЦИЯЛАР БИЛАН БОҒЛИҚ АЙРИМ ҚИЛМИШЛАРНИ КВАЛИФИКАЦИЯ ҚИЛИШ МАСАЛАЛАРИ //«Хуқуқий тадқиқотлар» электрон журнали. - 2020. - Т. 2. - №. SPECIAL 3.

10. Khaydarov Shukhratjon Djumayevich // GENERAL DESCRIPTION OF THE CRIME OF HIJACKING A VEHICLE // MODERN SCIENTIFIC CHALLENGES AND TRENDS: a collection scientific works of the International scientific conference (28th February, 2021) - Warsaw: Sp. z o. o. "iScience", 2021. Part 2 - 152 p.

https://sciencecentrum.pl/wpcontent/uploads/2021/03/MODERN_SCIEN TIFIC_CHALLENGES\%2037\%20Part\%202\%20 (web).pdf

11. Allanova A. Leaving and entering illegally the Republic of Uzbekistan (instructions and specific features) //Review of law sciences. - 2018. - T. 2. - №. 2. - C. 29.

12. ХУдайкУлОВ Ф. ВЗАИМООТНОШЕНИЯ И УГОЛОВНО-ПРАВОВЫЕ АСПЕКТЫ ФАКУЛЬТАТИВНЫХ ОБЪЕКТИВНОЙ ПРИЗНАКОВ СТОРОНЫ
ПРЕСТУПЛЕНИЯ //Review of law sciences. - 2018. - №. 3.

13. Мамажанов А. М. ИСлОМ ХУқуқиДА РУХИЙ ХОЛАТИ БУЗИЛГАН ШАХСЛАРНИНГ ЖИНОИЙ ЖАВОБГАРЛИГИ //«Хуқуқий тадқиқотлар» электрон журнали. - 2020. - T. 2. - №. SPECIAL 3. (Mamajanov Abrorbek Mirabdullayevich. Criminal liability of persons with a mental disorder in Islamic law. Journal of Law Research. 2020, special issue 3, pp. 209-215)

14. Vokhid S. SPECIFIC ASPECTS OF MOTIVATION AND PURPOSE IN THE QUANTIFICATION OF CAREER FRAUD CRIME //Review of law sciences. - 2020. №. 4. 